\title{
Ortaokul Öğretmenlerinin Müdür Kavramına İlişkin Metaforik Algıları*
}

\section{Secondary School Teachers' Metaphorical Perceptions of the Concept of Principal}

\section{Mehmet KORKMAZ**}

\author{
Mehmet Sabir ÇEVİK***
}

ABSTRACT: In this research which was carried out in screening model to find out the perceptions of the secondary school teachers, concerning the concept of "principal" through metaphors, phenomenology, one of the qualitative research designs was utilized. Research group is composed of 210 voluntary teachers working in 16 secondary schools in the central district of Siirt in 2016-2017 school year, through maximum variation sampling method. Research data was collected through a semi-structured form consisting statements such as "School principal is as ..., because ...". In the evaluation of research data, "content analysis" method was utilized. As a result of the research, it was determined that teachers use 96 metaphors in relation to school principals, which were categorized under 11 different themes. Accordingly, teachers mostly perceive school principals as "a guiding and leading person". However, the category with the least metaphors and the least participation is the category: "School Principal as the person storing information". Moreover, it was found out that teachers have a high level of metaphors of school principals. In the research, it was generally concluded that teachers have a positive metaphors of school principals.

Keywords: teacher, school principal, secondary school, metaphor.

ÖZ: Ortaokul öğretmenlerinin “müdür” kavramına ilişkin sahip oldukları algıları metaforlar yoluyla ortaya çıkarmayı amaçlayan tarama modelindeki bu araştırmada, nitel araştırma desenlerinden biri olan olgu bilim (fenomenoloji) deseni kullanılmıştır. Araştırmanın çalışma grubu, 2016-2017 eğitim-öğretim yılında maksimum çeşitlilik örneklemesi yoluyla Siirt merkezde 16 ortaokulda görev yapan ve gönüllü olarak çalışmaya katılan 210 öğretmenden oluşmaktadır. Araştırmanın verileri "Okul müdürü ............ gibidir; çünkü ............." ifadesinin yer aldığı yarı yapılandırılmış bir form aracılığıyla toplanmıştır. Araştırma verilerinin değerlendirilmesinde "içerik analizi" tekniği kullanılmıştır. Araştırma sonucunda öğretmenlerin okul müdürlerine yönelik 96 farklı metafor ürettiği belirlenmiştir. $\mathrm{Bu}$ metaforlar, farklı temalar altında 11 kategoride toplanmıştır. Buna göre öğretmenler okul müdürlerini ağırlıklı olarak "Yol Gösterici ve Lider Biri Olarak" algılamaktadır. Bunun yanı sıra en az metafor ve en az öğretmen katılımın olduğu kategorinin ise "Bilginin Depolayıcısı Olarak Okul Müdürü" kategorisi olduğu saptanmıştır. Diğer taraftan öğretmenlerin okul müdürlerine ilişkin çok sayıda farklı metafor ürettiği bulgulanmıştır. Araştırmanın geneli itibariyle öğretmenlerin okul müdürlerine ilişkin metaforlarının olumlu olduğu sonucuna varılmıştır.

Anahtar kelimeler: öğretmen, okul müdürü, ortaokul, metafor.

\footnotetext{
* This research presented as an oral statement in the 8th International Education Management Forum (EYFOR-8) held in Ankara between 19 and 21 October 2017.

** Corresponding Author. Prof. Dr., Gazi University, Ankara, Turkey, korkmaz@gazi.edu.tr

Doctoral student, Hacettepe University, Ankara, Turkey, sahici1980@gmail.com

Citation Information

Korkmaz, M. \& Çevik, M. S. (2018). Ortaokul öğretmenlerinin müdür kavramına ilişkin metaforik algıları. Kuramsal Eğitimbilim Dergisi [Journal of Theoretical Educational Science], 11(4), 973-1002.
} 


\section{Giriş}

Başarılı bir okul ortamı için güçlü liderlere ihtiyaç vardır. Okul müdürlerinin kendini sürekli geliştirebilen, teknolojiyi yakından takip edebilen, okul ve çevreyle iyi ilişkiler kurabilen, sorumluluk sahibi birer lider olmaları gerekmektedir (Edmonds, 1979). Başka bir anlatımla okul müdürleri, okulla alakalı tüm amaçları gerçekleştirmeye çalışan, okulun gelişimi için gerekli olan kaynakları bir araya getiren ve çalışanlarını her yönüyle geliştirmeye çalışan lider kişiler olmak zorundadır (Hoy \& Miskel, 2010; Karip, 2004). Balcı'ya (2014) göre de okul müdürleri okulların gelişim ve iyileştirme sürecinde anahtar bir rol oynamakla beraber aynı zamanda katalizör ve koordinatör olmak durumundadır. Bu bakımdan okul yöneticilerinin başkalarıyla olan ilişkilerde bazı yeterliklere sahip olmaları oldukça önemlidir (Turan, Yıldırım, \& Aydoğdu, 2012).

Geleneksel olarak okul müdürlerinin asli görevi okulu yönetmek, okulun vizyonunu ve misyonunu gerçekleştirmektir. Geçen yüzyılda okul müdürünün rolleri mevzuatı uygulamak, okul bütçesini dengeli bir şekilde kullanmak, okul ve çevre ilişkisini sağlıklı bir biçimde yürütmek olarak görülmüştür (Morrison, 2007; Usdan, 2000). Bu süreç içerisinde okul müdürü, 1950'lerde yasal lider, 1970'lerde insan ilişkilerini düzenleyen yönetici, 1980'lerde okul geliştirme uzmanı, 1990'larda öğretimsel lider ve 2000'lerde ise hesap verebilirliğe dayalı reformcu ve girişimci olarak görev yapmıştır (Portin, Alejano, Knapp, \& Marzolf, 2006; aktaran, Balyer, 2012). Aslında okul müdürlerinin, okulu geleceğe taşıyabilmek ve değişime ayak uydurabilmek için daha fazla sorumluluk almaları gerekmektedir. Bunun için de, okul müdürü geleneksel yönetim anlayışlarında olduğu gibi odalarına kapanıp günlük yazışmaları ve ilişkileri sürdürmenin ötesinde, okuldaki ilişkileri ve değerleri anlamaya çalışan, okulu öğrenmenin merkezi yapan lider olmalıdır. Dolayısıyla okul müdürlerinin çağa cevap verebilecek yönetişim, öğretim liderliği, vizyoner liderlik, sembolik liderlik, değişim, program geliştirme ve toplumsal ilişkiler konularında donanımlı olmaları gerekmektedir (Gündüz \& Balyer, 2013).

Korkmaz’a (2005) göre okul yöneticisinin yönetimde başarılı olmasında sahip olduğu kişisel nitelikler önemli olabilmektedir. Eğer okul yöneticisi, sağduyulu, meslektaşlarını ve öğrencileri etkileyebilen, bilgileri kullanabilme konusunda yeterli niteliklere sahipse o okulun başarılı olması için hiçbir engel yok demektir. Çınkır da (2010) okulların yaşanan hızlı değişim ve gelişmelere ayak uydurabilmeleri için okul müdürlerinin karar verme ve sorun çözmede gerekli bilgi ve beceriye sahip olmaları gerektiğini ifade etmektedir. $\mathrm{Bu}$ bağlamda okul müdürlerinin okulun amaçlarının gerçekleşmesinde okulla ilgili tüm paydaşlara öncülük etmesi gereken yöneticiler olmaları gerektiği düşünüldügünde okul müdürlerinin nasıl algılandığının belirlenmesi önemli bir hâle gelmektedir. $\mathrm{Bu}$ amacı gerçekleştirebilmek için ortaokul öğretmenlerinin zihinlerinde oluşan okul müdürü kavramına yönelik metafor algılarını tespit etmek yararlı olabilir.

Metafor sözcüğü Yunanca "değişmek" anlamına gelen meta ve "aktarmak" anlamına gelen pherein sözcüklerinin bir araya gelmesiyle oluşan metapherein sözcügünden meydana gelmektedir (Levine, 2005). Türk Dil Kurumu sözlüğünde metafor (mecaz / benzetme); "bir kavramı ilgi veya benzetme sonucu gerçek anlamının dışında başka anlamlara gelecek biçimde kullanma" olarak tanımlanmaktadır (Türk Dil Kurumu [TDK], 2017). Başka bir anlatımla metafor, bir kavramı veya olguyu başka bir kavrama ya da olguya benzeterek açıklamaya çalışmaktır (Nikitina \& Furuoka, 2008; 
Palmquist, 2001). Pipen'e (2001) göre metafor, karmaşık durumları ve söylenmek isteneni başkalarına pratik ve kalıcı yoldan ifade etmektir.

Metafor, bir bakıma söylenmek isteneni daha az kelimeyle ve daha etkileyici bir şekilde ifade etmeye yarar. Dolayısıyla metaforlar, özgün düşünmeyi ve olayları farklı yönleriyle görmeyi sağlayarak, duygu ve düşünceleri başkalarına aktarmada kaçınılmaz bir araç haline gelmektedir (Girmen, 2007). Metaforlar, anlaşılmayan değerlendirmeleri şekillendirmesi, soyut fikirleri somutlaştırması ve bilgiyi bütünsel bir yaklaşımla yeni bakış açıları kazandırarak sunması bakımından da avantaj sağlar (Jacobs \& Heracleous, 2006). Bunun yanı sıra metaforlar, olası yanlış anlamaların ortaya çıkmasını engeller (Fretzin, 2001). Ayrıca metaforlar, doğru bilgileri ortaya çıkararak kişilerin, yaşamları ve tecrübeleri arasında örüntü oluşturur, bilinçli veya bilinçsiz bir şekilde doğruları ve gerçekleri ifade etmeye yarar (Lakoff \& Johnson, 2003). Shuell (1990) metaforların etki derecesini "bir resim bin kelimeye bedelse, bir metafor da bin resme bedeldir" şeklinde ifade etmiştir.

Balcı'ya (2008) göre insanlar sadece günlük hayatta değil, örgütsel hayatta da metaforlardan sıklıkla yararlanırlar. Çünkü metaforlar, farklı bakış açılarını yansıtması nedeniyle örgütlerin daha iyi anlaşılmasına yardımcı olur. Nitekim eğitim yönetimi açısından metaforların, okulun örgütsel sistemini anlamada ve okul yöneticilerinin davranışlarını ve rollerini değerlendirmede önemli bir ölçüt olduğu anlaşılmaktadır (Balc1, Demirkasımoğlu, Erdoğan, \& Akın, 2011). Metaforların bu özelliği, örgüt yöneticilerinin sürekli etkileşim halinde oldukları örgüt üyelerince nasıl algıladıklarının tespit edilmesini sağlamaktadır (Yalçın \& Erginer, 2012). Günümüzde de metaforlar, var olan sorunlara yanıt bulma sürecinde bir araç olarak kullanılmaktadır. Bu eğilimin oluşmasında metaforların kişilerin özgür düşünme sistemini geliştirmesi, düşünceleri tek bir kelimeyle ifade edebilmesi, farkına varılmayan detayların anlaşılması ve duyuşsal alana ilişkin verilerin elde edilmesini sağlaması etkili olmuştur (Koç, 2014).

Literatürde okul müdürlerine ilişkin metaforik araştırmalar incelendiğinde okul müdürlerine yönelik değişik zamanlarda farklı bakış açılarının olduğu görülür. Bu çerçevede litaratürdeki bazı araştırmalarda (Aydoğdu, 2008; Balc1, 1999; Inbar, 1996; Karademir, 2008; Lum, 1997; Pantina, 1991; Yalçın \& Erginer, 2014; Yıldırım \& Uğur, 2011) okul müdürleri olumsuz bir unsur olarak algılanmakta iken; bazı araştırmalarda ise (Akan, Yalçın, \& Yıldırım, 2014; Boydak Özan \& Şener, 2014; Browne-Ferrigno, 2003; Cerit, 2008; Dönmez, 2008; Koçak, 2011; Linn, Sherman \& Gill, 2007; Monroe, 2003; Örücü, 2014; Pesen, Kara, \& Gedik, 2015; Trnavcevic \& Vaupot, 2009; Tüzel \& Şahin, 2014; Yalçın, 2011; Yalçın \& Erginer, 2012) okul müdürlerine ilişkin algıların olumlu bir yönde seyir izlediği saptanmıştır. Cerit (2008), okul müdürlerine yönelik algılardaki bu farklılı̆̆ı, meydana gelen yeni gelişmeler bağlamında yöneticilerin davranışlarının değişiminden kaynaklanabileceğini belirtmektedir. Nitekim Goodwin, Cunningham, \& Eagle de (2005) araştırmalarında okullarda tek egemen kişinin okul müdürleri olmadığını ve müdür otoritesinin zayıflamasına doğru bir yönelim olduğu bulgulamıştır.

Eğitim alanında yapılan metaforik araştırmalar, sadece okul müdürleriyle sınırlı değildir. Metaforik araştırmaların aynı zamanda öğretmenlere (Afacan, 2011; Aydeş, 2015; Aydın \& Pehlivan, 2010; Buraphan, 2011; Cerit, 2008; Çocuk, Yokuş, \& Tanrıseven, 2015; Ekiz \& Koçyiğit, 2013; Kalyoncu, 2012; Koç, 2014; Mahlios \& Maxson, 1998; Nikitina \& Furuoka, 2008; Ocak \& Gündüz, 2006; Oğuz, 2009; Oxford vd., 1998; Özdemir \& Erol, 2015; Saban, 2004; Shaw \& Mahlios, 2008; Ünal \& Ünal, 
2010; Yalçın, Yılmaz \& Karakaya, 2017; Y1lmaz, Göçen, \& Yılmaz, 2013; Zhao, Coombs, \& Zhou, 2009), müfettişlere (Dinç, 2016; Memduhoğlu \& Mazlum, 2014; Töremen \& Döş, 2009), okula (Aydoğdu, 2008; Balc1, 2011; Doğan, 2013; Koçak, 2013; Nalçacı \& Bektaş, 2012; Özdemir, 2012; Saban, 2008; Toker Gökçe \& Bülbül, 2014; Tulunay Ateş, 2016), sınıf yönetimine (Akar \& Yıldırım, 2009), eğitim programlarına (Gültekin, 2013; Semerci, 2007), öğrenme ve öğretim (Carter \& Pitcher, 2010; Elmholdt, 2003; Font, Bolite, \& Acevedo, 2010; Levine, 2005; Saban, Koçbeker, \& Saban, 2006; Taşdemir \& Taşdemir, 2011) gibi çeşitli konulara yönelik olduğu da görülür. Bu araştırmalara ilaveten ortaokul müdürlerine yönelik metaforik algıları içeren bir araştırmanın öğretmenlerin müdürlerine karşı besledikleri çeşitli duyguları ortaya çıkarabilir. Bu doğrultuda araştırmanın, literatüre kayda değer katkılar yapacağı düşünülmektedir.

$\mathrm{Bu}$ araştırma, okul müdürlerinin okulda nasıl bir yönetim anlayışı sergilediklerini göstermesi bakımından önemli sayılabilir. Çünkü, okul müdürlerine ilişkin metaforik çalışmalar, okulların nasıl yönetildiği konusunda ipuçları sağlayabilir. Nitekim Yalçın ve Erginer'e (2012) göre okul müdürlerine yönelik algılar, eğitimöğretim faaliyetlerinin kalitesini etkilemekte ve okul müdürü bu algılar sayesinde olumlu davranışlarını devam ettirmektedir. Ayrıca araştırmanın, ortaokul müdürlerinin yeterlilikleri konusunda ilgili kişilere rehberlik edeceği ve okul müdürlerinin okul içerisinde gerçekleştirmek zorunda oldukları rollerde ve sahip olmaları gereken niteliklerin belirlenmesinde yol gösterici nitelikte olacağı tahmin edilmektedir.

\section{Araştırmanın Amacı}

$\mathrm{Bu}$ araştırmanın amacı ortaokullarda görev yapan öğretmenlerin "müdür" kavramına ilişkin algılarını metaforlar yoluyla tespit etmektir. Bu amacı gerçekleştirebilmek için aşağıdaki sorulara yanıt aranmıştır:

1. Öğretmenlerin "müdür" kavramına ilişkin sahip oldukları metaforlar nelerdir?

2. Bu metaforlar ortak özellikleri bakımından hangi kavramsal kategoriler altında toplanabilir?

\section{Yöntem}

\section{Araştırma Modeli}

Öğretmenlerin "müdür” kavramına ilişkin sahip oldukları algıları metaforlar yoluyla ortaya çıkarmayı amaçlayan tarama modelindeki bu araştırmada, nitel araştırma desenlerinden biri olan olgu bilim (fenomenoloji) deseni kullanılmıştır. Olgu bilim deseni, katılımcıların olgulara ilişkin yaşantı ve anlamlarını tespit ederek, farklı bakış açılarıyla olguları anlamlandırmayı amaçlayan nitel araştırma desenidir (Creswell ve John, 2013; McMillan, 2004).

\section{Çalışma Grubu}

Araştırmanın çalışma grubu, 2016-2017 Eğitim-Öğretim yılında maksimum çeşitlilik örneklemesi yoluyla Siirt il merkezinde 16 ortaokulda görev yapan ve gönüllü olarak çalışmaya katılmış 244 öğretmenden oluşmaktadır. Ancak 34 öğretmenin verileri "müdür" kavramına ilişkin metaforlara uygun olmadığından araştırmadan çıkartılmış olup geri kalan 210 öğretmenin verileri araştırmaya dahil edilmiştir. Maksimum 
çeşitliliğe dayalı bir örneklemde temel amaç, çeşitlilik gösteren durumlar arasında ortak veya paylaşılan olguların olup olmadığını bulmaya çalışmak ve bu çeşitliliğe göre problemin farklı boyutlarını belirlemektir (Yıldırım \& Şimşek, 2013). Araştırmaya katılan öğretmenlerin 107'si (\%51) erkek, 103'ü (\%49) kadın olup 154'ü evli (\%73. 3), 56'sı bekârdır (\%26.7). Yaşa göre dağılımlar incelendiğinde öğretmenlerin 86's1 (\%41) 20-30 yaş arası, 100'ü (\%47.6) 31-40 yaş aras1, 24'ü (\%11.4) 41-50 yaş aras1 öğretmenlerden oluşmaktadır. Kıdem değişkeninde ise öğretmenlerin 79'u (\%37.6) 1-5 y11, 44'ü (\%21) 6-10 y1l, 50'si (\%23.8) 11-15 y1l, 15'i (\%7.1) 16-20 y1l, 22'si (\%10.5) 21 y1l ve üzeri hizmete sahiptir. Öğretmenlerin 202'si (\%96.2) lisans, 8'si (\%3.8) yüksek lisans mezunudur.

\section{Verilerin Toplanması ve Analizi}

Araştırmaya katılan öğretmenlere "müdür" kavramına ilişkin algılarını belirlemek amaciyla "Okul müdürü gibidir; çünkü ............................" ifadesinin yer aldığı yarı yapılandırılmış bir form dağıtılmıştır. Araştırmanın verilerinin değerlendirilmesinde içerik analizi tekniği kullanılmıştır. İçerik analizi, söylenenleri ve yazılanları belirli kriterlere göre kodlayıp sayısallaştırma süreci olarak tanımlanabilir. Başka bir deyişle içerik analizi, birbirine benzeyen verileri belli kategoriler ve temalar çerçevesinde bir araya getirerek, okuyucunun anlayabileceği bir şekilde organize edip yorumlamaktır (Balc1, 2015; Yıldırım \& Şimşek, 2013).

Öğretmenlerin ürettikleri metaforların analiz edilmesi metafor çalışmalarında başvurulan 5 aşamada gerçekleştirilmiştir: Adlandırma aşamasında öğretmenlerin geliştirdikleri metaforlar ve cümleler incelenmiştir. Üretilen metaforlar alfabetik sıraya göre listelenmiştir. Metafor olarak sayılmayacak kavramlar alan uzmanına teyit ettirilerek işaretlenmiştir. Eleme (tasnif) aşamasında katılımcıların "müdür" kavramıyla ilgili olmayan metaforları değerlendirme dışı bırakılmıştır. Buna bağlı olarak 34 öğretmenin verileri çalışma kapsamından çıkarılmış, geçerli metaforları üreten 210 öğretmenin verileri çalışmaya dahil edilmiştir. Bu işlemler gerçekleştirilirken her bir metaforun konusu, metaforun kaynağı ve metaforun konusu ile metaforun kaynağ 1 arasındaki ilişki göz önünde bulundurulmuştur. Kategori aşamasında öğretmenler tarafından üretilen metaforlar "müdür” kavramına ilişkin sahip oldukları ortak nitelikler yönünden incelenerek 11 farklı kavramsal kategori oluşturulmuştur. Geçerlik ve güvenirlilik aşamasında 11 kategoride toplanan metaforların bir kavramsal kategoriyi temsil edip etmediğini tespit etmek amaciyla uzman görüşüne başvurulmuştur. $\mathrm{Bu}$ amaçla uzman kişiye metaforun alfabetik sıraya göre dizili olduğu liste ile farklı kategorilerin adlarını ve özelliklerini içeren bir liste verilmiştir. Uzman kişiden bu iki listeyi de kullanarak metafor listesini, ikinci listedeki farklı kategorilerle ve hiçbir metafor dışarda kalmayacak şekilde eşleştirmesi istenmiştir. Uzmanın yaptığ eşleştirmeler ile araştırmacının yapmış olduğu eşleştirmeler birbirleriyle karşılaştırılmıştır. Karşılaştırmalarda araştırmanın güvenilirliği Miles ve Huberman'ın (1994) formülü (Güvenirlik = Görüş Birliği / Görüş Birliği + Görüş Ayrllı̆gl) kullanılarak hesaplandı. Görüşüne başvurulan uzman, 7 metaforu farklı kategorilere yerleştirerek ilişkilendirmiştir. Buna göre müdür kavramına ilişkin araştırmanın güvenirlik çalışmasında \%93 (Güvenirlik $=100 /(100+7)=0.93)$ oranında bir uzlaşma sağlanmıştır. Bununla beraber görüş ayrılığı olan eşleştirmelerde de gerekli düzeltmelere gidilerek, eşleştirmelerde tam bir uzlaşma sağlanmıştır. Saban’a (2009) 
göre nitel araştırmalarda 0.90 ve üzeri güvenirlik aranır. Buna göre araştırmanın güvenirliliğinin yeterli olduğu söylenebilir. Verilerin bilgisayara aktarma aşamasında ise tüm veriler, bilgisayar ortamına aktarılarak araştırmanın frekans (f) değerleri hesaplanmıştır. Ayrıca araştımaya katılan öğretmenler "Ö" harfiyle kodlanmış ve her katılımcının kodunun yanına bir numara (Ö1, Ö2, Ö3 ... gibi) verilmiştir.

\section{Bulgular}

\section{Öğretmenlerin “Müdür” Kavramına Yönelik Ürettikleri Metaforlar}

$\mathrm{Bu}$ araştırmanın genel bulgularına göre öğretmenlerin "müdür" kavramına yönelik ürettikleri metaforlar ve bunları temsil eden öğretmen sayıları (f) Tablo 1'de verilmiştir.

Tablo 1

“Müdür” Kavramına Yönelik Üretilen Metaforlar ve Onları Temsil Eden Öğretmen Saylst

\begin{tabular}{|c|c|c|c|c|c|}
\hline Sira No & Metafor Ad 1 & Frekans $(f)$ & Sira No & Metafor Ad 1 & Frekans $(f)$ \\
\hline 1. & Ağaç & 1 & 51. & Hücre Çekirdeği & 9 \\
\hline 2. & Ağaç Kökü & 4 & 52. & İnşaat Temeli & 3 \\
\hline 3. & Aile Büyüğü & 1 & 53. & İskelet & 1 \\
\hline 4. & Ampül & 1 & 54. & Kalp & 2 \\
\hline 5. & Anne & 2 & 55. & Karınca & 2 \\
\hline 6. & Apt. Yöneticisi & 2 & 56. & Kolon & 3 \\
\hline 7. & Araba Şasesi & 1 & 57. & Köprü & 1 \\
\hline 8. & Ar1 & 4 & 58. & Kumanda Merkezi & 1 \\
\hline 9. & Arkadaş & 2 & 59. & Kütüphane & 1 \\
\hline 10. & Aslan & 1 & 60. & Lider & 4 \\
\hline 11. & Aşç1 & 1 & 61. & Limon & 1 \\
\hline 12. & Atom Karınca & 1 & 62. & Lokomotif & 4 \\
\hline 13. & Ayna & 3 & 63. & Motor & 1 \\
\hline 14. & Baba & 13 & 64. & Muhtar & 1 \\
\hline 15. & Bahçıvan & 1 & 65. & Mum & 1 \\
\hline 16. & Bal & 1 & 66. & Nar Kabuğu & 1 \\
\hline 17. & Baş & 1 & 67. & Ombudsman & 1 \\
\hline 18. & Başbakan & 2 & 68. & Orkestra Şefi & 4 \\
\hline 19. & Başhekim & 1 & 69. & Oyun Kurucu & 1 \\
\hline 20. & Bayrak & 1 & 70. & Padişah & 1 \\
\hline 21. & Bekçi & 1 & 71. & Paratoner & 1 \\
\hline 22. & Bel Kemiği & 2 & 72. & Patron & 1 \\
\hline 23. & Beyin & 10 & 73. & Rehber & 2 \\
\hline
\end{tabular}




\begin{tabular}{|c|c|c|c|c|}
\hline 24. & Bilg. İşlemcisi & 3 & 74. & Reis \\
\hline 25. & Bukalemun & 1 & 75 & Robin Hood \\
\hline 26. & Bulut & 1 & 76. & Roman Yazarı \\
\hline 27. & Büryan Kebabı & 1 & 77. & Rüzgar \\
\hline 28. & Can Simidi & 2 & 78. & Saat \\
\hline 29. & CEO & 1 & 79. & Satrançtaki Şah \\
\hline 30. & Cevap Anahtarı & 1 & 80 & Sayılar \\
\hline 31. & Cumhurbaşkanı & 2 & 81. & Sünger \\
\hline 32. & Çatı & 1 & 82. & Şoför \\
\hline 33. & Çimento & 3 & 83. & Takım Kaptanı \\
\hline 34. & Çoban & 2 & 84. & Tangram \\
\hline 35. & Danışman & 2 & 85. & Teknik Direktör \\
\hline 36. & Demir & 1 & 86. & Tencere \\
\hline 37. & Deniz Feneri & 2 & 87. & Terazi \\
\hline 38. & Dişi Kuş & 1 & 88. & Tesbih İmamesi \\
\hline 39. & Dünya & 1 & 89. & Toka \\
\hline 40. & Fiil Çatısı & 1 & 90. & Trafik Polisi \\
\hline 41. & Gemi Kaptanı & 13 & 91. & Tuz \\
\hline 42. & Gökkuşağ1 & 1 & 92. & Türkiye \\
\hline 43. & Günah Keçisi & 1 & 93. & Yap1ştırıcı \\
\hline 44. & Hakem & 1 & 94. & Yönetmen \\
\hline 45. & Hakim & 1 & 95. & Yumurtlayan Yumurta \\
\hline 46. & Halay Başı & 1 & 96. & Zincir \\
\hline 47. & Hamur & 1 & & \\
\hline 48. & Harf & 1 & & \\
\hline 49. & Hayat & 1 & & \\
\hline 50. & Renk Çemberi & 1 & & \\
\hline
\end{tabular}

\begin{tabular}{lc} 
Toplam Öğretmen Sayısı & 210 \\
\hline Toplam Metafor Sayısı & 96
\end{tabular}

Tablo 1'de görüldüğü gibi öğretmenler “müdür” kavramına ilişkin 96 farklı metafor olmak üzere toplam 210 metafor üretmiştir. Bununla birlikte öğretmenlerin en fazla geliştirdikleri metaforun "Teknik Direktör $(f=15)$ " metaforu olduğu görülmektedir. Üretilen 96 metafordan 6'sının (Baba, Beyin, Hücre Çekirdeği, Gemi Kaptanı, Takım Kaptanı, Teknik Direktör) 9 ile 15 öğretmen tarafından, geri kalan metaforların ise 1 ile 4 öğretmen tarafından geliştirildiği anlaşılmaktadır. 


\section{Öğretmenlerin “Müdür” Kavramına Yönelik Ürettikleri Metaforların Oluşturduğu Kategoriler}

Öğretmenlerin "müdür" kavramıyla ilgili ürettikleri metafor çeşitlerinin ortak özellikleri yönünden kategorilere göre sınıflandırılmasına Tablo 2'de yer verilmiştir.

Tablo 2

Öğretmenlerin Ürettikleri Metafor Çeşitlerinin Kategorilere Göre Dağılımı

\begin{tabular}{clcc}
\hline Sıra No & Kategoriler & Metafor adedi & Yüzdelik (\%) \\
\hline 1 & Birleştirici ve Dengeleyici Unsur Olarak Okul Müdürü & 14 & 14.6 \\
2 & Denetleyici ve Güç Unsuru Olarak Okul Müdürü & 5 & 5.21 \\
3 & Bilginin Depolayıcısı Olarak Okul Müdürü & 1 & 1.04 \\
4 & Değerli ve Vazgeçilmez Biri Olarak Okul Müdürü & 7 & 7.29 \\
5 & Zavallı ve Acınacak Biri Olarak Okul Müdürü & 2 & 2.04 \\
6 & Değişken Biri Olarak & 14 & 14.6 \\
7 & Okul Müdürü & & \\
8 & Koruyucu ve Güven Verici Biri Olarak Okul Müdürü & 14 & 14.6 \\
9 & Sorun Çözücü Biri Olarak Okul Müdürü & 3 & 3.12 \\
10 & Yönetim Odağı Olarak Okul Müdürü & 13 & 13.54 \\
11 & Yol Gösterici ve Lider Biri Olarak Okul Müdürü & 19 & 19.8 \\
\hline Toplam & Çalışkan Biri Olarak Okul Müdürü & 4 & 4.16 \\
\hline
\end{tabular}

Tablo 2'ye göre öğretmenlerin “müdür” kavramına ilişkin geliştirdikleri metaforlar toplam 11 kategoride toplanmıştır. En fazla metafor sayısı "Yol Gösterici ve Lider Biri Olarak Okul Müdürü" kategorisinde iken; en az metafor ise "Bilginin Depolayıcısı Olarak Okul Müdürü” kategorisinde olduğu görülmektedir. Bununla beraber geri kalan kategorilerin metafor sayısının 2 ile 14 arasında değiştiği saptanmıştır. Tablo 3 ile Tablo 13 arasında söz konusu kategorilerde yer alan metaforlar ve açıklama örneklerine yer verilmiştir.

\section{Birleştirici ve Dengeleyici Unsur Olarak Okul Müdürü}

Tablo 3'te "Birleştirici ve Dengeleyici Unsur Olarak Okul Müdürü” kategorisini oluşturan metaforlar ve her bir metafora ilişkin öğretmen sayısı verilmiştir.

Tablo 3'te görüldüğü gibi bu kategoriyi 18 öğretmen ve 14 metafor temsil etmektedir. 14 adet geçerli metafordan 12 tanesini sadece 1 öğretmen, diğer 2 metaforun ise 2 ile 4 arasında öğretmen tarafından üretildiği bulgulanmıştır. Bu kategoride en çok "A ğaç Kökü $(f=4)$ ve Terazi $(f=2)$ " metaforları tekrarlanmıştır. Aşağıda bu kategorideki metaforları üreten öğretmenlerin örnek ifadeleri yer almaktadır.

"Okul müdürü, bir bayanın tokası gibidir; çünkü toka yerinde olmazsa saçlar dağılır ve ahenk bozulur (Ö7)."

“Okul müdürü, bir ağacın kökleri gibidir; çünkü ağacın kökleri dalların birleşim noktasıdır ve dalları bir arada tutar (Ö145)." 
“Okul müdürü, aşçı gibidir; çünkü aşçı yemeğin her bakımdan kıvamında olmasını sağlar (Ö201)."

“Okul müdürü, yapıştırıcı gibidir; çünkü yapıştırıcı parçaları birleştirerek bütünlüğü sağlar (Ö39).”

“Okul müdürü, zincir gibidir; çünkü zincir, halkalar arasında bağlantıyı sağlar (Ö88).”

“Okul müdürü, terazi gibidir; çünkü müdür, okulun hassas denge unsurudur (Ö98).”

“Okul müdürü, köprü gibidir; çünkü müdür, herkesi aynı paydada birleştirir (Ö102).”

“Okul müdürü, tantuniye sıkılan limon gibidir; çünkü limon, tantuniye çok sıkılırsa ekşi, az sikılırsa tatsız olur (Ö54).”

\section{Tablo 3}

Birleştirici ve Dengeleyici Unsur Olarak Okul Müdürü

\begin{tabular}{lc}
\hline Metafor Adı & Frekans $(f)$ \\
\hline Ağaç Kökü & 4 \\
Aşçı & 1 \\
Çatı & 1 \\
Fiil Çatısı & 1 \\
Köprü & 1 \\
Limon & 1 \\
Nar Kabuğu & 1 \\
Roman Yazarı & 1 \\
Tangram & 1 \\
Tencere & 1 \\
Terazi & 2 \\
Toka & 1 \\
Yapıştırıcı & 1 \\
Zincir & 1 \\
\hline Toplam Öğretmen Sayısı & 18 \\
\hline Toplam Metafor Sayısı & 14 \\
\hline
\end{tabular}

\section{Denetleyici ve Güç Unsuru Olarak Okul Müdürü}

Tablo 4'te "Denetleyici ve Güç Unsuru Olarak Okul Müdürü” kategorisini oluşturan metaforlar ve her bir metafora ilişkin öğretmen sayısı verilmiştir.

Tablo 4'te görüldüğü gibi bu kategoriyi 5 öğretmen ve 5 metafor temsil etmektedir. $\mathrm{Bu}$ kategorideki tüm metaforlar 1'er öğretmen tarafından üretilmiştir. Aşağıda bu kategorideki metaforları üreten öğretmenlerin örnek ifadeleri yer almaktadır.

"Okul müdürü, saat gibidir; çünkü okul müdürü, her şeyin yerinde ve zamanında yapılmasını ister (Ö94)."

"Okul müdürü, cevap anahtarı gibidir; çünkü nasıl ki soruların cevaplarını cevap anahtarından kontrol ediyorsak, okul müdürü de öğretmenlerin yanlış hareketlerini düzeltir ve kontrol eder (Ö41)."

"Okul müdürü, patron gibidir; çünkü sürekli eksiklikleri tespit edip denetler (Ö56)." 
“Okul müdürü, hakim gibidir; çünkü her şeyin mevzuata göre yapılmasını ister (Ö208).”

Tablo 4

Denetleyici ve Güç Unsuru Olarak Okul Müdürü

\begin{tabular}{lc}
\hline Metafor Adı & Frekans $(f)$ \\
\hline Cevap Anahtarı & 1 \\
Hakim & 1 \\
Patron & 1 \\
Saat & 1 \\
Trafik Polisi & 1 \\
\hline Toplam Öğretmen Sayısı & 5 \\
\hline Toplam Metafor Sayısı & 5 \\
\hline
\end{tabular}

\section{Bilginin Depolayıcısı Olarak Okul Müdürü}

Tablo 5'te "Bilginin Depolayıcısı Olarak Okul Müdürü" kategorisini oluşturan metafor ve bu metafora ilişkin öğretmen sayısı verilmiştir.

Tablo 5

Bilginin Depolayıcısı Olarak Okul Müdürü

\begin{tabular}{lc}
\hline Metafor Adı & Frekans $(f)$ \\
\hline Kütüphane & 1 \\
\hline Toplam Öğretmen Sayısı & 1 \\
Toplam Metafor Sayısı & 1 \\
\hline
\end{tabular}

Tablo 5'te görüldüğü gibi bu kategoriyi sadece 1 öğretmen ve 1 metafor temsil etmektedir. Aşağıda bu kategorideki metaforu üreten öğretmenin ifadesi yer almaktadır.

“Okul müdürü, kütüphane gibidir; çünkü merak ettiğin ve öğrenmek istediğin her şeyi kütüphanede bulabilirsin (Ö185).” 


\section{Değerli ve Vazgeçilmez Biri Olarak Okul Müdürü}

Tablo 6'da "Değerli ve Vazgeçilmez Biri Olarak Okul Müdürü" kategorisini oluşturan metaforlar ve her bir metafora ilişkin öğretmen sayısı verilmiştir.

\section{Tablo 6}

Değerli ve Vazgeçilmez Biri Olarak Okul Müdürü

\begin{tabular}{lc}
\hline Metafor Adı & Frekans $(f)$ \\
\hline Araba Şasesi & 1 \\
Bel Kemiği & 2 \\
Bayrak & 1 \\
Çimento & 3 \\
İnşaat Temeli & 3 \\
Kolon & 3 \\
Sayılar & 2 \\
\hline Toplam Öğretmen Sayısı & 15 \\
Toplam Metafor Sayısı & 7 \\
\hline
\end{tabular}

Tablo 6'da görüldüğü gibi bu kategoriyi 15 öğretmen ve 7 metafor temsil etmektedir. 7 adet geçerli metafordan 2 tanesini sadece 1 öğretmen, diğer 5 metaforu ise 2 ile 3 arasında öğretmen tarafından üretildiği tespit edilmiştir. Bu kategoride en çok "Çimento $(f=3)$, İnşaat Temeli $(f=3)$ ve Kolon $(f=3)$ " metaforları tekrarlanmıştır. Aşağıda bu kategorideki metaforları üreten öğretmenlerin örnek ifadeleri yer almaktadır.

“Okul müdürü, araba şasesi gibidir; çünkü araba şasesi olmazsa, arabanın diğer parçalarının hiçbiri çalışmaz (Ö201).”

"Okul müdürü, bir binanın kolonu gibidir; çünkü binayı ayakta tutan kolonlar olmazsa bina ayakta duramaz. Müdürsüz bir okulun da bir anlamı yoktur (Ö111).”

“Okul müdürü, matematikteki sayılar gibidir; çünkü sayılar olmadan toplama, çıkarma, çarpma ve bölme işlemi yapamazsınız (Ö40).”

“Okul müdürü, bir vücudun bel kemiğidir; çünkü müdür, okulun olmazsa olmazıdır (Ö79).”

“Okul müdürü, bayrak gibidir; çünkü bayrak bir milleti temsil eder. Ne zaman ki bayrak düşürse o millet de yıkılır. Müdürsüz bir okul da çökmeye mahkumdur (Ö198).” 


\section{Zavallı ve Acınacak Biri Olarak Okul Müdürü}

Tablo 7'de "Zavallı ve Acınacak Biri Olarak Okul Müdürü” kategorisini oluşturan metaforlar ve her bir metafora ilişskin öğretmen sayısı verilmiştir.

Tablo 7

Zavallı ve Acınacak Biri Olarak Okul Müdürü

\begin{tabular}{lc}
\hline Metafor Adı & Frekans $(f)$ \\
\hline Günah Keçisi & 1 \\
Sünger & 1 \\
\hline Toplam Öğretmen Sayısı & 2 \\
Toplam Metafor Sayısı & 2 \\
\hline
\end{tabular}

Tablo 7'de görüldüğü gibi bu kategoriyi 1 öğretmen ve 1 metafor temsil etmektedir. Her 2 metaforun da 1'er öğretmen tarafından üretildiği tespit edilmiştir. Aşağıda bu kategorideki metaforları üreten öğretmenlerin örnek ifadeleri yer almaktadir.

"Okul müdürü, günah keçisi gibidir; çünkü okuldaki gerçekleşen her şeyden doğrudan veya dolaylı olarak sorumlu tutulur (Ö25)."

"Okul müdürü, sünger gibidir; çünkü okulla ilgisi olan herkesin her türlü sıkıntısını çeker (Ö61).”

\section{Değişken Biri Olarak Okul Müdürü}

Tablo 8'de "Değişken Biri Olarak Okul Müdürü" kategorisini oluşturan metaforlar ve her bir metafora ilişkin öğretmen sayısı verilmiştir.

Tablo 8'de görüldüğü gibi bu kategoriyi 17 öğretmen ve 14 metafor temsil etmektedir. 14 adet geçerli metafordan sadece 1 tanesinin 4 öğretmen, diğer metaforların ise 1'er öğretmen tarafından üretildiği görülmektedir. Bu kategoride en çok "Rüzgar $(f=4)$ " metaforu tekrarlanmıştır. Aşağıda bu kategorideki metaforları üreten öğretmenlerin örnek ifadeleri yer almaktadır.

"Okul müdürü, rüzgar gibidir; çünkü ne zaman gürleyeceği ve ne zaman eseceği belli olmaz (Ö204)."

“Okul müdürü, hamur gibidir; çünkü istediğiniz zaman, istediğiniz şekle sokabilirsiniz (Ö171).”

“Okul müdürü, bukalemun gibidir; çünkü her ortama uyum sağlamaktadır (Ö133).”

“Okul müdürü, dünya gibidir; çünkü gerektiğinde gece gibi her şeyin üstünü örter, gerektiğinde gündüz gibi her şeyi aydınlatır (Ö88)."

“Okul müdürü, alfabedeki harf gibidir; çünkü harfler cümle başında büyük, kelime aralarında ise küçük yazılır. Müdür de duruma göre davranmayı iyi bilen kişidir (Ö122).”

“Okul müdürü, büryan kebabı gibidir; çünkü her sabah farklı bir şekilde tadına varılarak güne başlanır (Ö202).”

“Okul müdürü, yumurtlayan yumurta gibidir; çünkü sürprizlerle doludur (Ö11).”

“Okul müdürü, bulut gibidir; çünkü gerektiğinde sıcaktan koruyan bir şemsiye, gerektiğinde de hayat veren yağmurdur (Ö187).” 
Tablo 8

Değişken Biri Olarak Okul Müdürü

\begin{tabular}{lc}
\hline Metafor Adı & Frekans $(f)$ \\
\hline Bal & 1 \\
Bulut & 1 \\
Büryan Kebabı & 1 \\
Bukalemun & 1 \\
Dünya & 1 \\
Gökkuşağı & 1 \\
Hakem & 1 \\
Hamur & 1 \\
Harf & 1 \\
Hayat & 1 \\
Renk Çemberi & 1 \\
Rüzgar & 4 \\
Tuz & 1 \\
Yumurtlayan Yumurta & 1 \\
\hline Toplam Öğretmen Sayısı & 17 \\
\hline Toplam Metafor Sayısı & 14 \\
\hline
\end{tabular}

\section{Koruyucu ve Güven Verici Biri Olarak Okul Müdürü}

Tablo 9'da “Koruyucu ve Güven Verici Biri Olarak Okul Müdürü” kategorisini oluşturan metaforlar ve her bir metafora ilişkin öğretmen sayısı verilmiştir.

Tablo 9'da görüldüğü gibi bu kategoriyi 29 öğretmen ve 14 metafor temsil etmektedir. 14 adet geçerli metafordan 10 tanesini 1 öğretmen, diğer 4 metaforu ise 2 ile 13 arasında öğretmen tarafından üretildiği bulgulanmıştır. Bu kategoride en çok "Baba $(f=13)$ " metaforu tekrarlanmıştır. Aşağıda bu kategorideki metaforları üreten öğretmenlerin örnek ifadeleri yer almaktadır.

“Okul müdürü, paratoner gibidir; çünkü okulu birçok tehlikeye karşı korur (Ö168).”

“Okul müdürü, Türkiye gibidir; çünkü kendi bünyesinde kim varsa hepsine kol kanat olur (Ö148).”

“Okul müdürü, baba gibidir; çünkü her türlü sorunda çalışanlarının yanında olur (Ö103).”

“Okul müdürü, bekçi gibidir; çünkü okulu türlü tehlikelere karşı ayakta tutar (Ö180).”

“Okul müdürü, anne gibidir; çünkü onun gölgesi bize güven veriyor (Ö4).”

“Okul müdürü, ağaç gibidir; çünkü şefkatini her zaman hissederiz (Ö49).”

“Okul müdürü, can simidi gibidir; çünkü tehlikeli zamanlarda bizi yalnız bırakmaz (Ö104).” 
Tablo 9

Koruyucu ve Güven Verici Biri Olarak Okul Müdürü

\begin{tabular}{lc}
\hline Metafor Adı & Frekans $(f)$ \\
\hline Ağaç & 1 \\
Anne & 2 \\
Aile Büyüğü & 1 \\
Arkadaş & 2 \\
Baba & 13 \\
Bahçıvan & 1 \\
Bekçi & 1 \\
Can Simidi & 2 \\
Demir & 1 \\
Dişi Kuş & 1 \\
İskelet & 1 \\
Paratoner & 1 \\
Robin Hood & 1 \\
Türkiye & 1 \\
\hline Toplam Öğretmen Sayısı & 29 \\
\hline Toplam Metafor Sayısı & 14 \\
\hline
\end{tabular}

\section{Sorun Çözücü Biri Olarak Okul Müdürü}

Tablo 10’da “Sorun Çözücü Biri Olarak Okul Müdürü” kategorisini oluşturan metaforlar ve her bir metafora ilişkin öğretmen sayısı verilmiştir.

Tablo 10

\section{Sorun Çözücü Biri Olarak Okul Müdürü}

\begin{tabular}{lc}
\hline Metafor Adı & Frekans $(f)$ \\
\hline Apartman Yöneticisi & 2 \\
Danışman & 2 \\
Ombudsman & 1 \\
\hline Toplam Öğretmen Sayısı & 5 \\
\hline Toplam Metafor Sayısı & 3 \\
\hline
\end{tabular}

Tablo 10'da görüldüğü gibi bu kategoriyi 5 öğretmen ve 3 metafor temsil etmektedir. 3 adet geçerli metafordan 1 tanesinin 1 öğretmen, diğerlerinin ise 2'şer öğretmen tarafından üretildiği görülmektedir. Bu kategoride en çok "Apartman Yöneticisi $(f=2)$ ve Danışman $(f=2)$ " metaforu tekrarlanmıştır. Aşağıda bu kategorideki metaforları üreten öğretmenlerin örnek ifadeleri yer almaktadır.

"Okul müdürü, apartman yöneticisi gibidir; ortaya çıkan problemleri en kısa sürede çözmeye çalışır (Ö24)." 
"Okul müdürü, danışman gibidir; çünkü bize rehberlik ederek sorunlarımızı çözer (Ö75)."

"Okul müdürü, ombudsman gibidir; çünkü sorunların çözüm merkezidir (Ö146).”

\section{Yönetim Odağı Olarak Okul Müdürü}

Tablo 11'de "Yönetim Odağı Olarak Okul Müdürü” kategorisini oluşturan metaforlar ve her bir metafora ilişkin öğretmen sayısı verilmiştir.

\section{Tablo 11}

\section{Yönetim Odăğ Olarak Okul Müdürü}

\begin{tabular}{lc}
\hline Metafor Adı & Frekans $(f)$ \\
\hline Aslan & 1 \\
Başbakan & 2 \\
Baş & 1 \\
Beyin & 10 \\
Bilgisayar İşlemcisi & 3 \\
Cumhurbaşkanı & 2 \\
Hücre Çekirdeği & 9 \\
Kalp & 2 \\
Kumanda Merkezi & 1 \\
Muhtar & 1 \\
Padişah & 1 \\
Satrançtaki Şah & 1 \\
Yönetmen & 4 \\
\hline Toplam Öğretmen Sayısı & 38 \\
Toplam Metafor Sayısı & 13
\end{tabular}

Tablo 11'de görüldüğü gibi bu kategoriyi 38 öğretmen ve 13 metafor temsil etmektedir. 13 adet geçerli metafordan 6 tanesinin 1 öğretmen, diğer metaforların 2 ile 10 öğretmen tarafindan üretildiği görülmektedir. Bu kategoride en çok "Beyin $(f=10)$ ve Hücre Çekirdeği $(f=9)$ " metaforu tekrarlanmıştır. Aşağıda bu kategorideki metaforları üreten öğretmenlerin bazı örnek ifadeleri yer almaktadır.

"Okul müdürü, vücuttaki beyin gibidir; çünkü beyin sağlıklı işlerse vücudun diğer organları da sağl1klı işler (Ö5)."

"Okul müdürü, bilgisayar işlemcisi gibidir; çünkü bilgisayar işlemcisi, bilgisayarın tüm iş ve işlemlerden sorumlu olan ana kumanda merkezidir (Ö91)."

"Okul müdürü, hücre çekirdeği gibidir; çünkü çekirdek, hücrede meydana gelen olayları yönetir (Ö63)."

"Okul müdürü, satrançtaki şah gibidir; çünkü şah olmadan diğer taşların hiçbir fonksiyonu olmaz (Ö111)."

"Okul müdürü, başbakan gibidir; çünkü ondan habersiz hiçbir şey yapılamaz. (Ö2)."

"Okul müdürü, yönetmen gibidir; çünkü okul müdürü de yönetmen gibi öğretmenlerin yapacakları işler hakkında direktifler verir (Ö90)." 
“Okul müdürü, vücudun kalbi gibidir; çünkü kalp, vücuda kanı pompalamazsa diğer uzuvların bir işlevi olmaz (Ö204).”

"Okul müdürü, cumhurbaşkanı gibidir; çünkü okuldaki yapılar arasında koordineyi sağlar (Ö81)."

\section{Yol Gösterici ve Lider Biri Olarak Okul Müdürü}

Tablo 12'de "Yol Gösterici ve Lider Biri Olarak Okul Müdürü” kategorisini oluşturan metaforlar ve her bir metafora ilişkin öğretmen sayısı verilmiştir.

\section{Tablo 12}

Yol Gösterici ve Lider Biri Olarak Okul Müdürü

\begin{tabular}{|c|c|}
\hline Metafor Adı & Frekans $(f)$ \\
\hline Ampül & 1 \\
\hline Ayna & 3 \\
\hline Başhekim & 1 \\
\hline CEO & 1 \\
\hline Çoban & 2 \\
\hline Deniz Feneri & 2 \\
\hline Gemi Kaptanı & 13 \\
\hline Halay Başı & 1 \\
\hline Lider & 4 \\
\hline Lokomotif & 4 \\
\hline Mum & 1 \\
\hline Orkestra Şefi & 4 \\
\hline Oyun Kurucu & 1 \\
\hline Şoför & 3 \\
\hline Rehber & 2 \\
\hline Reis & 1 \\
\hline Takım Kaptanı & 12 \\
\hline Teknik Direktör & 15 \\
\hline Tesbih İmamesi & 1 \\
\hline Toplam Öğretmen Sayısı & 72 \\
\hline Toplam Metafor Sayısı & 19 \\
\hline
\end{tabular}

Tablo 12'de görüldüğü gibi bu kategoriyi 72 öğretmen ve 19 metafor temsil etmektedir. 19 adet geçerli metafordan 8 tanesinin 1 öğretmen, diğer metaforların 2 ile 15 öğretmen tarafından üretildiği görülmektedir. Bu kategoride en çok "Teknik Direktör $(f=15)$, Gemi Kaptanı $(f=13)$ ve Takım Kaptanı $(f=12)$ " metaforu tekrarlanmıştır. Aşağıda bu kategorideki metaforları üreten öğretmenlerin örnek ifadeleri yer almaktadır.

“Okul müdürü, teknik direktör gibidir; çünkü öğretmenlere takım ruhunu aşılar (Ö23).” 
"Okul müdürü, gemi kaptanı gibidir; çünkü gemiyi yolcularıyla birlikte limana sağsalim ulaştırır (Ö72)."

"Okul müdürü, orkestra şefi gibidir; çünkü faklı seslerden güzel bir ahengin oluşmasına katk1 verir (Ö50)."

"Okul müdürü, deniz feneri gibidir; çünkü bize nereye gideceğimizi gösterir (Ö28).”

"Okul müdürü, CEO gibidir; çünkü hedefe odaklanmamızı sağlar (Ö164)."

"Okul müdürü, ampul gibidir; çünkü ampul, bizi karanlıktan kurtarır (Ö45)."

"Okul müdürü, lokomotif gibidir; çünkü tutum ve davranışlarıyla bize öncülük eder (Ö55)."

"Okul müdürü, çoban gibidir; çünkü çoban olmazsa sürü dağılır (Ö104)."

"Okul müdürü, halay başı gibidir; çünkü halay başı olmadan oyun ekibi aynı anda hareket edemez (Ö91)."

"Okul müdürü, takım kaptanı gibidir; çünkü iyi sonuç almak için takım oyuncularını iyi yönlendirmek gerekir (Ö138)."

"Okul müdürü, şoför gibidir; çünkü şoför, yolcuları varacakları yere güvenli bir şekilde ulaştıran en önemli kişidir (Ö162)."

"Okul müdürü, rehber gibidir; çünkü bütün iş ve işlemlerde bize yol gösterir (Ö32)."

"Okul müdürü, mum gibidir; çünkü çevresine 1şık saçar (Ö105)."

"Okul müdürü, ayna gibidir; çünkü okul müdürü, öğretmenlere kılavuzluk eder (Ö49).”

\section{Çalışkan Biri Olarak Okul Müdürü}

Tablo 13'te "Çalışkan Biri Olarak Okul Müdürü” kategorisini oluşturan metaforlar ve her bir metafora ilişkin öğretmen sayısı verilmiştir.

Tablo 13

\section{Çalışkan Biri Olarak Okul Müdürü}

\begin{tabular}{lc}
\hline Metafor Adı & Frekans $(f)$ \\
\hline Arı & 4 \\
Atom Karınca & 1 \\
Karınca & 2 \\
Motor & 1 \\
\hline Toplam Öğretmen Sayısı & 8 \\
\hline Toplam Metafor Sayısı & 4 \\
\hline
\end{tabular}

Tablo 13'te görüldüğü gibi bu kategoriyi 8 öğretmen ve 4 metafor temsil etmektedir. 4 adet geçerli metafordan 2 tanesini sadece 1 öğretmen, diğer 2 metaforu ise 2 ile 4 arasında öğretmen tarafından üretildiği saptanmıştır. Bu kategoride en çok "Ar1 $(f=4)$ ve Karınca $(f=2)$ " metaforları tekrarlanmıştır. Aşağıda bu kategorideki metaforları üreten öğretmenlerin örnek ifadeleri yer almaktadır.

“Okul müdürü, atom karınca gibidir; çünkü okul müdürü, yorulmak nedir bilmeyen ve okul için çaba sarf eden kişidir (Ö73).”

“Okul müdürü, bir makinanın motoru gibidir; çünkü okul müdürü, sürekli okulu için bir şeyler yapmaya çalışır (Ö14).”

“Okul müdürü, karınca gibidir; çünkü çok çalışarak okula yeni şeyler kazandırıyor (Ö178).”

“Okul müdürü, arı gibidir; çünkü okul müdürü, gündüzünü gecesine katıp durmaksızın çalışmaktadır (Ö157).” 


\section{Sonuç ve Tartışma}

$\mathrm{Bu}$ araştırma, ortaokullarda görev yapan öğretmenlerin “müdür” kavramına yönelik sahip oldukları algılarını metaforlar yoluyla ortaya çıkarmak ve bu metaforların hangi kavramsal kategoriler altında toplandığını belirmek amacıyla gerçekleştirilmiştir.

Araştırmanın sonucunda 210 öğretmen “müdür” kavramına ilişkin 96 adet metafor geliştirmiştir. Araştırma metaforları, 11 farklı kavramsal kategoriye ayrıldığında en çok metafor bulunan kategorilerinin birinci sırada 19 metaforla "Yol Gösterici ve Lider Biri Olarak Okul Müdürü”, ikinci sırada 14'er metaforla "Birleştirici ve Dengeleyici Unsur Olarak Okul Müdürü, Değişken Biri Olarak Okul Müdürü, Koruyucu ve Güven Verici Biri Olarak Okul Müdürü” ve üçüncü sırada 13 metaforla "Yönetim Odağı Olarak Okul Müdürü" kategorilerinin olduğu görülmektedir. En az metafor üretilen kategori ise 1 metaforla "Bilginin Depolayıcısı Olarak Okul Müdürü", kategorisidir. Araştırmanın bu sonuçları, Aydoğdu (2008), Browne-Ferrigno (2003), Cerit (2008), Dönmez (2008), Fennel (1996), Koçak (2011), Monroe (2003), Pesen vd. (2015), Yalçın (2011), Yalçın \& Erginer'in (2012), araştırma sonuçlarıyla benzerlik göstermektedir.

"Birleştirici ve Dengeleyici Unsur Olarak Okul Müdürü” kategorisini oluşturan metaforlar incelendiğinde bu araştırmanın Dönmez (2008), Yalçın (2011), Yalçın \& Erginer'in (2012) araştırmalarındaki metaforlarla benzer bir kategoriyi oluşturduğu görülmektedir. Araştırmanın bu sonucuna göre öğretmenlerin, okul müdürünü öğretmen, öğrenci ve veli gibi okulla ilgili tüm paydaşlar arasında bağlantıyı ve irtibatı sağlayan biri olarak gördükleri anlaşılmaktadır. Başka bir anlatımla öğretmenler okul müdürünü, herkesin buluştuğu ortak nokta olarak görme eğilimindedir. Okul müdürünün bu işlevinin, okul içerisinde örgütsel ahengi ve örgütsel sürekliliği sağlaması açısından önemli olduğu söylenebilir. Çünkü okul müdürü, okul içinde bütün farklılıkların bir arada buluşabileceği ana kilit noktasıdır. Bununla beraber bu kategoride üretilen metaforlar, okul müdürünün öğretmenler arasında ayrım gözetmeyen bir yönetim anlayışına sahip olması gerektiği sonucunu da ortaya çıkarmaktadır. Zira okul içinde dengeyi sağlamanın yolu okul müdürlerinin tutarlı karar ve uygulamalarıyla gerçekleşir. Bu nedenle bir okul müdürünün birleştirici ve dengeleyici olma özelliği okullar için gerekli, öğretmenler için ise olumlu bir sonuç olarak yorumlanabilir.

"Denetleyici ve Güç Unsur Olarak Okul Müdürü” kategorisini oluşturan metaforlara bakıldığında öğretmenlerin okul müdürlerini yapılan işlerin zamanında ve yerinde yapılmasını sağlayan, kontrol eden kişiler olarak algılandıkları anlaşılmaktadır. $\mathrm{Bu}$ işlerin kontrol edilmesi aşamalarında ise okul müdürünün sahip olduğu yasal ve bürokratik otoritenin devreye girdiği söylenebilir. Araştırmanın bulguları Aydoğdu (2008), Cerit (2008), Fennel (1996), Inbar (1996), Koçak (2011), Yalçın \& Erginer'in (2012) araştırma bulgularıyla paralellik göstermekle beraber bu kategoride okul müdürlerinin "denetleyici” işlevlerine vurgu yapan metaforların olmasıyla da farklı özelikler göstermektedir. Aydın’a (2011) göre okul gibi eğitim kurumlarının belirlenmiş amaçlara ne düzeyde ulaştıklarını tespit etmek için denetim ve kontrol mekanizmaları kurmak gereklidir. Ancak bu kategorideki metaforik algıların az olması araştırmaya konu olan okul müdürlerinin "denetim" rollerini tam ve istendik seviyede yapmadıkları / yapamadıklarının bir göstergesi sayılabilir. Bu sonucun ortaya çıkmasında okul müdürlerinin aynı anda eğitim-öğretim dışında çok sayıda işle meşgul olmasının etkili olduğu tahmin edilmektedir. 
Araştırmanın en az metafor üretilen kategorisi "Bilginin Depolayıcısı Olarak Okul Müdürü” kategorisi olmuştur. Pesen vd. (2015) ve Yalçın \& Erginer'in (2012) araştırmalarında da bu kategoriye yönelik metafor sayısının diğer kategorilere göre daha az olduğu bulgulanmıştır. Aslında bu kategoriye ilişkin metafor sayısının az olması okul müdürlerinin alanlarıyla ilgili sahip oldukları bilgi seviyesinin düşük olduğunun bir kanıtı olarak gösterilebilir. $\mathrm{Bu}$ durum, okul müdürlerinin atanırken ciddi ve objektif kriterler sağlanmadan seçilmelerinin bir neticesi olarak açıklanabilir. Başka bir deyişle okul müdürü atamalarında bilgili ve donanımlı olmanın dışında farklı subjektif ölçütlerin etkili olduğu söylenebilir. Bu sonuç da okul müdürleri açısından olumsuz bir durum olarak görülebilir.

"Değerli ve Vazgeçilmez Biri Olarak Okul Müdürü” kategorisindeki metaforlar incelendiğinde öğretmenlerin okul müdürlerini okulun olmazsa olmazı olarak algıladıkları sonucuna ulaşılabilir. Öğretmenlere göre okul, müdürüyle anlam kazanarak ayakta kalabilmektedir. Bunun yanı sıra geliştirilen metaforlardan, öğretmenlerin okul müdürleriyle ilişkilerinde duygusal bir bağla bağlandıkları ve okul müdürlerini benimseyip içselleştirdikleri anlaşılmaktadır. Aydoğdu (2008), Yalçın \& Erginer (2012) araştırmalarında da okul müdürünü "değerli” bir varlık olarak niteleyen metaforların olduğu görülür. Dolayısıyla araştırmanın bu sonucu, alanyazının desteklediği bir sonuçtur. Nitekim Yalçın \& Erginer (2012) okul müdürlerinin değerli bir varlık olarak görülmesini, okul müdürünün öğretmenlerle iyi ilişkiler kurması, öğretmenlerin sorunlarını dinlemesi, ögretmenlere yardımcı olması ve olumlu bir okul ortamı oluşturması gibi değişik faktörlerle açıklamaktadır.

"Zavallı ve Acınacak Biri Olarak Okul Müdürü” kategorisinde yer alan metaforlar, okul müdürünün her şeyden sorumlu olması sebebiyle acınacak bir kişi olarak görülmesinin bir göstergesi olabilir. Bir bakıma çok az sayıdaki öğretmen, okul müdürlüğü görevinin yapılmayacak bir görev olduğu düşüncesindendir. Bu sonuçta, en küçük bir hatada bile sorguya ve hesaba çekilecek olan kişinin, okulun başı olarak okul müdürü olması etkili olmuş olabilir. Ayrıca bu kategorideki metaforlardan, okul müdürlerini herkesin sıkıntısıyla muhatap olan kişi olarak da görüldüğü sonucuna ulaşılabilir. Dönmez'in (2008) araştırmasında da okul müdürlerinin görevleri, üretilen metaforlarla "çok sorumluluk taşıyan" kategoriyle ilişkilendirilmişken; Karademir' in (2008) araştırmasında ise "zor ve riskli bir iş" ile ilişsilendirilmiştir. Bu yönüyle araştırmanın sonucu Dönmez'in (2008) ve Karademir'in (2008) araştırma sonuçlarıyla benzerlik göstermektedir.

"Değişken Biri Olarak Okul Müdürü” kategorisini oluşturan metaforlar incelendiğinde okul müdürlerine yönelik bazı ifadelerin olumsuz bir mesaj içerdiği saptanmıştır. Pesen vd. 'in (2015) araştırmasında da böyle bir sonuç ortaya çıkmıştır. Bu kategorideki öğretmenlerin bir kısmı, okul müdürlerinin yönetim anlayışlarının tutarsız ve değişken olduğunu düşünmekte iken; bir kısmı da ürettikleri metaforlarla okul müdürlerinin olumlu yönlerine vurgu yapmaktadır. Başka bir ifadeyle öğretmenler, okul müdürlerinin farklı tutum ve davranışlarını farklı bir şekilde yorumlamıştır. Bu durum, öğretmenlerin okul müdürüne yönelik bakış açılarının farklı olmasıyla izah edilebilir.

"Koruyucu ve Güven Verici Biri Olarak Okul Müdürü” kategorindeki metaforlar, öğretmenlerin okul müdürlerini adeta sığınabilecekleri güvenli bir liman olarak gördüklerinin bir göstergesi olarak görülebilir. Bunun yanı sıra okul müdürlerinin tüm öğretmenlerin rahat ve güvenli bir ortamda çalışmalarını sağlayarak, öğretmenlere 
sevgiyle yaklaştıkları tahmin edilmektedir. Öğretmenlerin bu kategoride fazla metafor üretmesi okul müdürleri açısından istendik bir sonuç olarak yorumlanabilir. Çünkü, bir öğretmen ancak kendini emin ve güvende hissettiği ortamda öğrencilerine faydalı olabilir. Yalçın'a (2011) göre öğretmenlerin kendilerini güvende hissetmesi kaliteli bir eğitim-öğretime yardımcı olabilir. Literatürde Akın Kösterlioğlu (2014), Cerit (2008), Dönmez (2008), Gentilucci \& Muto (2007), Linn vd. (2007), Örücü (2015), Pesen vd. (2015), Tüzel \& Şahin (2014), Yalçın (2011), Yalçın \& Erginer (2012), Zembat, Tunçeli \& Akşin (2015) araştırmalarında bu araştırmanın sonuçlarıyla paralel sonuçlar ortaya çıkmıştır.

"Sorun Çözücü Biri Olarak Okul Müdürü" kategorisindeki metaforlar incelendiğinde, okul müdürlerinin bir kısmının okul içerisinde öğretmenler, öğrenciler ve veliler arasında zaman zaman ortaya çıkan problemleri çözme becerisine sahip oldukları anlaşılmaktadır. Okul müdürleri sadece kişilerarası ilişkilerden kaynaklı sorunları değil, aynı zamanda okulla ilgili sorun teşkil eden diğer konularla ilgili olarak da sorun çözücü olarak görülmektedir. Karşılaşılan sorunların çözümünde öğretmenlere destek olan okul müdürlerinin, öğretmenlerin okul yönetimine karşı olumlu duygular beslemesine zemin hazırladığ1 söylenebilir. Bunun da öğretmen ve yönetici iş birliğine katkı sağlayacağı düşünülmektedir. Bu kategorideki bulgular Linn vd. (2007), Pesen vd. (2015), Tvnavcevic \& Vaupot (2009), Yalçın \& Erginer'in (2012) araştırma sonuçlarıyla benzer özellikler taşımaktadır.

"Yönetim Odağı Olarak Okul Müdürü" kategorisinde üretilen metaforlara bakıldığında, öğretmenler, okul müdürünün asıl görevinin okulu, eldeki kaynaklarla verimli ve etkili bir şekilde yönetmek olduğunun farkındadırlar. Bu noktada okul müdürünün okulla alakalı diğer kişileri harekete geçiren en önemli kişi olduğu sonucuna da varılabilir. Ayrıca bu kategorideki öğretmenlerin, kendi branşlarıyla ilişki kurarak metafor geliştirdikleri saptanmıştır. Söz gelimi Fen Bilgisi öğretmeni okul müdürünü hücre çekirdeğine; Bilgisayar öğretmeni ise bilgisayar işlemcisine benzetmiştir. Araştırmanın bu sonucu da Pesen vd. (2015), Yalçın (2011), Yalçın \& Erginer'in (2012) araştırma sonucuyla paralellik göstermektedir.

"Yol Gösterici ve Lider Biri Olarak Okul Müdürü" kategorisi en fazla metafor üretilen kategoridir. Buna göre okul müdürlerinin, başta öğretmenler olmak üzere okulun tüm personeline, öğrencilere ve velilere kılavuzluk ettiği anlaşılmaktadır. Ayrıca öğretmenlerin okul müdürünün liderliğiyle amaçlar etrafında kenetlenebileceği ifade edilebilir. Yani öğretmenlerin, okul müdürlerini yol gösteren ve liderlik yapan kişiler olarak görmek istedikleri söylenebilir. Okul müdürünün iyi bir lider olarak okulu yönetmesi, öğrencilerin akademik başarılarına da katkı sağlayabileceği unutulmamalıdır. Araştırmanın bu kategoriye yönelik bulguları Aydoğdu (2008), Browne-Ferrigno (2003), Cerit (2008), Dönmez (2008), Fennel (1996), Koçak (2011), Monroe (2003), Pesen vd. 'nin (2015) araştırma bulgularıyla aynı özellikler göstermektedir.

"Çalışkan Biri Olarak Okul Müdürü” kategorisindeki ifadeler incelendiğinde okul müdürlerinin okulun ihtiyaçlarını gidermek amacıyla çaba sarf ettikleri ve okul için çalıştıkları söylenebilir. Bu sonucun ortaya çıkmasında okul müdürlerinin mesleklerini sevmeleri veya mesleklerini severek yapmalarının etkili olduğu tahmin edilmektedir. Ancak az sayıdaki öğretmenin bu kategoriye yönelik metafor geliştirmesi, okul müdürleri açısından bir eksiklik olarak da algılanabilir. Nitekim litarartürde Aydoğdu 
(2008), Dönmez (2008), Koçak (2011), Pesen vd. (2015) ve Yalçın'ın (2011) araştırmalarında da bu kategorinin metaforlarıyla örtüşen sonuçlar ortaya çıkmıştır.

Araştırmanın tüm bulguları birlikte incelendiğinde ortaokul öğretmenlerinin, okul müdürlerini hedeflere kenetlenme noktasında yol gösterici ve lider biri olarak gördükleri anlaşılmaktadır. Başka bir deyişle öğretmenler, okul müdürlerini okulla ilişkili herkese kılavuzluk eden, hedef gösteren ve harekete geçiren kişiler olarak algılamaktadır. Bu bağlamda araştırmaya konu olan okul müdürlerinin beklenen ve istenen liderlik rollerini yeterli düzeyde gerçekleştirdikleri ifade edilebilir. Araştırmanın bir diğer önemli sonucu ortaokul öğretmenlerinin okul müdürlerine yönelik algılarının genel olarak olumlu olmasıdır. Bu, okul müdürleri için avantajlı bir durum olarak düşünülebilir. Çünkü, okul müdürlerine karşı olumlu duyguları veya düşünceleri olan öğretmenlerin okulun amaçlarının gerçekleşmesinde ve eğitim kurumlarının işleyişinde önemli katkıları olacağı aşikârdır. Araştırmanın kayda değer bir başka sonuç ise öğretmenlerin okul müdürlerine ilişkin algılarının çok çeşitli ve zengin olmasıdır. Yani öğretmenler, okul müdürlerini her yönüyle bazı niteliklere ve yeterliliğe sahip, konumu itibariyle öğretmenlerin beklentilerine, sorunlarına cevap verebilen, geniş bakış açılı lider kişiler olarak görmektedir. Dolayısıyla araştırmaya katılan ortaokul öğretmenlerinin "müdür” kavramına yönelik düşüncelerinin dar ve yüzeysel olmadığ 1 sonucuna ulaşılmıştır.

\section{Öneriler}

Araştırmanın sonuçlarından yola çıkarak uygulayıcılara ve araştırmacılara şu önerilerde bulunulabilir;

- Öğretmenlerin geleceğin müdürleri olabileceğinden hareketle, üniversitelerin eğitim fakültelerinde "liderlik, yönetim, yöneticilik, mevzuat, halkla ilişkiler, diksiyon, iletişim” gibi konuları içeren derslerin okutulması zorunlu veya seçmeli olarak okutulmalıdır.

- Öğretmenlerin "müdür" kavramına yönelik algılarını ortaya çıkarmak için yapılmış bu araştırma, nicel çalışma biçiminde farklı değişkenlerle yapılabilir.

- $\mathrm{Bu}$ araştırma, ortaokullarda görev yapan öğretmenlerin algıları göz önünde tutularak yapılmıştır. Aynı araştırma yönetici, öğrenci, veli gibi farklı kişilerle ve farklı öğretim kurumlarında da tekrarlanabilir. 


\section{Summary}

Purpose: This research aims to determine the secondary school teachers' perception of "principal", through metaphors. Apart from this main objective, answers of the following questions were sought;

1. What metaphors do teachers use related to concept of "principal"?

2. Based on their common features, under which conceptual categories these metaphors can be classified?

Method: In this research, "phenomenology design", one of the qualitative research designs was utilized. Phenomenology design is a qualitative research design aiming to interpret the phenomenon based on different perspectives by determining the experiences and their meanings for the participants (Creswell \& John, 2013; McMillan, 2004).

Research group is composed of 210 voluntary teachers working in 16 secondary schools in the central district of Siirt in 2016-2017 school years, through maximum variation sampling method. In a sampling based on maximum variation, main aim is to find out whether there are common or joint phenomena among the varying cases, and according to this variation, to determine the different dimensions of the problem (Yildirım \& Şimşek, 2013).

Semi-structured forms consisting statements such as "School principal is as ..., because ....." were distributed to the teachers participating in the study. In the evaluation of research data, "content analysis" method was utilized. Content analysis may be defined as a process of coding the content based on certain criteria and digitalization of it accordingly. In other words, content analysis is the classification, organization and interpretation of similar data under certain categories and themes to make it understandable for the reader (Balcı, 2015; Yıldırım \& Şimşek, 2013).

Expert opinion was taken to determine whether the metaphors collected under 11 categories represent a conceptual category. To this end, a list of metaphors in alphabetical order and a list consisting of the names and features of different categories were provided to the expert. Then the expert was asked to match the list of metaphors with the different categories in the other list in a way not to exclude any metaphor. Matchings of the expert were compared with that of the researcher. Research reliability was evaluated through Miles and Huberman's (1994) formula (Reliability = Agreement / Agreement + Disagreement). The expert whose opinion was taken, matched 7 metaphors with different categories. Accordingly, reliability of the research on the concept of "principal" was found out to be $93 \%$ (Reliability $=100 /(100+7)=0.93$.

Results: Teachers developed 96 metaphors in relation to the concept of "principal". Moreover, the most common metaphor developed by teachers was the metaphor of "technical director $(f=15)$ ". It was observed that 6 out of 96 metaphors (Father, Brain, Cell Nucleus, Shipmaster, Team Captain, Coach) were developed by 9 to 15 teachers, and the rest by 1 to 4 teachers. Metaphors developed by teachers were classified under 11 categories as "School Principal as a Uniting and Balancing Factor, School Principal as a Supervisor and Power Factor, School Principal as the Person Storing Information, School Principal as a Valuable and Irreplaceable Person, School Principal as a Poor and 
Pitiful Person, School Principal as a Temperamental Person, School Principal as a Protecting and Assuring Person, School Principal as a Problem-Solving Person, School Principal as the Focus of Management, School Principal as the Guiding and Leading Person, School Principal as a Hardworking Person. Most of the metaphors are under the category of "School Principal as the Guiding and Leading Person", while the least is in "School Principal as the Person Storing Information". Moreover, the number of metaphors in the other categories varies between 2 and 14 .

Discussion and Conclusions: Results of the research support the assertions that metaphors are appropriate means to determine the perceptions and thoughts on a certain matter. According to the research, secondary school principals are perceived as people guiding, inspiring and motivating in matters relating to school. In this context, it may be stated that school principals who are the subject matter of this research perform the required and expected leadership roles at a sufficient level. Another important conclusion of the research is that secondary school teachers have a positive perception of principal in general. This may be considered as an advantage for school principals, as teachers with positive feelings and thoughts about their school principals would contribute greatly to the realization of school's objectives and functions. Another remarkable result of the research is that teachers' perception of principals is various and manifold. In other words, teachers consider that school principals are qualified and competent in every aspect and meet the expectations, answer the questions of teachers in relation to their position, and have a wide perspective. Accordingly, it is concluded that secondary school teachers participating in the research do not have a narrow and superficial perception of the concept "principal".

Depending on the results of the research, following suggestions can be made for the practitioners and researchers:

- Considering that the teachers may become principals in the future, courses such as "leadership, management, legislation, public relations, diction and communication" should be provided in education faculties either as optional or compulsory courses.

- This research carried out to find out about the teachers' perceptions of "principal" may be carried out as a quantitative study with different variables.

- This research was carried out by considering the perceptions of the secondary school teachers. It may be reiterated with different stakeholders such as administrators, students, parents; and in different educational institutions. 


\section{Kaynakça}

Afacan, Ö. (2011). Fen bilgisi öğretmen adaylarının "fen" ve "fen ve teknoloji öğretmeni” kavramlarına yönelik metafor durumları. e-Journal of New World Sciences Academy, 6(1), 1242-1254.

Akan, D., Yalçın, S., \& Yıldırım, İ. (2014). Teachers' metaphoric impressions related to school manager. Illkögretim Online, 13(1), 169- 179.

Akar, H., \& Y1ldırım, A. (2009). Change in teacher candidates' metaphorical images about classroom management in a social constructivist learning environment. Teaching in Higher Education, 14(4), 401-415.

Akın Kösterelioğlu, M. (2014). Öğretmen adaylarının okul yöneticisi kavramına ilişkin metaforik algıları. Zeitschriftü̈rdie Welt der Türken / Journal of World of Turks, 6(3), 115-133.

Aydeş, S. S. (2015). Okul yöneticilerinin öğretmenlere yönelik metaforik algıları (Yayımlanmamış yüksek lisans tezi). Gaziosmanpaşa Üniversitesi, Eğitim Bilimleri Enstitüsü, Tokat.

Aydın, M. (2011). Çă̆daş eğitim denetimi. Ankara: Hatipoğlu Yayınevi.

Aydın, İ. S., \& Pehlivan, A. (2010). Türkçe öğretmeni adaylarının “öğretmen” ve "öğrenci” kavramlarına ilişkin kullandıkları metaforlar. International Periodical Forthe Languages, Literature and History of Turkish or Turkic, 5(3), 818-842.

Aydoğdu, E. (2008). İlköğretim okullarındaki öğrenci ve öğretmenlerin sahip olduklart okul algllar ile ideal okul algılarının metaforlar (mecazlar) yoluyla analizi (Yayımlanmamış yüksek lisans tezi). Osmangazi Üniversitesi, Fen Bilimleri Enstitüsü, Eskişehir.

Balc1, A. (1999). Metaphorical images of school: school perceptions of students, teachers and parents from four selected schools (in Ankara) (Yayımlanmamış doktora tezi). Orta Doğu Teknik Üniversitesi, Sosyal Bilimler Enstitüsü, Ankara.

Balcı, A. (2008). Örgüt mecazları. Ankara: Pegem Akademi Yayıncılık.

Balcı, A., Demirkasımoğlu, N., Erdoğan, Ç., \& Akın, U. (2011). Turkish teachers' and supervisors' metaphorical perceptions about supervisors. International Research Journals, 2(10), 1602-1610.

Balcı, F. A. (2011). Okul metaforları: İlköğretim müfettişlerinin okul algıları. Eurasian Journal of Educational Research, 3(44), 27-38.

Balcı, A. (2014). Etkili okul ve okul geliştirme. Ankara: Pegem Yayıncılık.

Balcı, A. (2015). Sosyal bilimlerde araştırma yöntem, teknik ve ilkeler. Ankara: Pegem Yayıncilik.

Balyer, A. (2012). Çağdaş okul müdürlerinin değişen rolleri. Ahi Evran Üniversitesi, Kırşehir Eğitim Fakültesi Dergisi (KEFAD), 13(2), 75-93. 
Boydak Özan, M., \& Şener, G. (2014). Öğretmenlerin okul müdürü algılarının liderlik modellerine göre incelenmesi: Firat ili örneği. Fırat Üniversitesi Harput Araştırmaları Dergisi, 1(2), 111-130.

Browne-Ferrigno, T. (2003). Becoming a principal: Role conception, initial socialization, role-identity transformation, purposeful engagement. Educational Administration Quarterly, 39(4), 468-503.

Buaraphan, K. (2011). Metaphorical roots of beliefs about teaching and learning science and their modifications in the standard based science teacher preparation programme. International Journal of Science Education, 33(11), 1571-1595.

Carter, S., \& Pitcher, R. (2010). Extended metaphors for pedagogy: using sameness and difference, Teaching in Higher Education, 15(5), 579-589.

Cerit, Y. (2008). Öğrenci, öğretmen ve yöneticilerin müdür kavramı ile ilgili metaforlara ilişkin görüşleri. Eğitim ve Bilim, 33(147), 3-13.

Creswell, John W. (2013). Qualitative inquiry \& research design: Choosing among five approaches. Los Angeles: SAGE Publications.

Çınkır, Ş. (2010). İlköğretim okulu müdürlerinin sorunları: sorun kaynakları ve destek stratejileri. Illkögretim Online, 9(3), 1027-1036.

Çocuk, H. E., Yokuş, G., Tanrıseven, I. (2015). Pedagojik formasyon öğrencilerinin öğretmenliğe ilişkin özyeterlik ve metaforik algıları: Mersin üniversitesi örneği. Mustafa Kemal Üniversitesi Sosyal Bilimler Enstitüsü Dergisi, 12, 373-387.

Dinç, M. (2016). Okul müdürlerinin maarif müfettişlerine ilişkin görüşlerinin meteforik olarak incelenmesi (Denizli ili merkez Edendi ilçesi örneği) (Yayımlanmamış tezsiz yüksek lisans projesi). Pamukkale Üniversitesi, Eğitim Bilimleri Enstitüsü, Denizli.

Doğan, D. (2013). Öğretmen adaylarının perspektifinden okul kavramının metaforlarla analizi. Kuramsal Ĕ̈itim Bilim Dergisi, 7(3), 361-382.

Dönmez, Ö. (2008). Türk eğitim sisteminde kullanılan yönetici metaforları (Kayseri ili örneği) (Yayımlanmamış yüksek lisans tezi). Erciyes Üniversitesi, Sosyal Bilimler Enstitiüsü, Kayseri.

Edmonds, R. R. (1979). Effective Schools for The Urban Poor. Educational Leadership, $37,15-27$.

Ekiz, D., \& Koçyiğit, Z. (2013). Sınıf öğretmenlerinin “öğretmen” kavramına ilişkin metaforlarının tespit edilmesi. Kastamonu Ĕ̈itim Dergisi, 21(2), 439-458.

Elmholdt, C. (2003). Metaphors for learning: cognitive acquisition versus social participation. Scandinavian Journal of Educational Research, 47(2), 116-32.

Fennel, H. A. (1996). An exploration of principals' metaphors for leaders and power. http://www.eric.ed.gov/contentdelivery/servlet/ERICServlet?accno=ED399626 Erişim Tarihi: 14/09/2017).

Font, V., Bolite, J., \& Acevedo, J. (2010). Metaphors in mathematics classrooms: analyzing the dynamic process of teaching and learning of graph functions. Educational Studies in Mathematics, 54(2), 131-152. 
Fretzin, L. (2001). http://lrs.ed.uiuc.edu/students/fretzin/EPL11q5Metaphors.htm. (Erişim Tarihi: 15/10/2017).

Gentilucci L. J., \& Muto C. C. (2007). Principals' influence on academic achievement: the student perspective. NASSP Bulletin, 91(3), 219-236.

Girmen, P. (2007). İlköğretim öğrencilerinin konuşma ve yazma sürecinde metaforlardan yararlanma durumları (Yayınlanmamış doktora tezi). Anadolu Üniversitesi, Eğitim Bilimleri Enstitüsü, Eskişehir.

Goodwin, R., Cunningham, M., \& Eagle, T. (2005). The changing role of the secondary principal in the United States: An historical perspective. Journal of Educational Administration and History, 37(1), 1-17.

Gültekin, M. (2013). İlköğretim öğretmen adaylarının eğitim programı kavramına yükledikleri metaforlar. Eğitim ve Bilim, 38(169), 126-141.

Gündüz, Y., \& Balyer, A. (2013). Gelecekte okul müdürlerinin gerçekleştirmeleri gereken roller. Anadolu Üniversitesi Sosyal Bilimler Dergisi, 13(3), 45-54.

Hoy, W. K., \& Miskel, C. G. (2010). Eğitim yönetimi teori, araştırma ve uygulama. (Çeviri Ed.: S. Turan). Ankara: Nobel Dağıtım.

Inbar, D. (1996). The free educational prison: Metaphors and images. Educational Research, 38(1), 77-92.

Jacobs, C., \& Heracleous, L. T. (2006). Constructing shared understanding: The role of embodied metaphors in organization development, Journal of Applied Behavioral Science, 42, 207-226.

Kalyoncu, R. (2012). Görsel sanatlar öğretmeni adaylarının “öğretmenlik” kavramına ilişkin metaforları Mustafa Kemal Üniversitesi Sosyal Bilimler Enstitüsü Dergisi, 9(20), 471-484.

Karademir, H. (2008). Illköğretim okullarında okul müdürlerine ait iletişimin öğrenciler tarafindan algl düzeyleri (Yayımlanmamış yüksek lisans tezi). Yeditepe Üniversitesi, Sosyal Bilimler Enstitüsü, İstanbul.

Karip, E. (2004). Yönetim biliminin alan ve kapsam1. Y. Özden, (Ed.), Eğitim ve okul yöneticiliği el kitabı (s. 1-39). Ankara: Pegem Yayıncılık.

Koç, E. S. (2014). Sınıf öğretmeni adaylarının öğretmen ve öğretmenlik mesleği kavramlarına ilişkin metaforik algıları. İnönü Üniversitesi Eğitim Fakültesi Dergisi, 15(1), 47-72.

Koçak, O. (2011). Okul müdürlerinin; öğrencilik, öğretmenlik ve müdürlük dönemlerindeki okul yöneticiliğine ilişkin metaforik algıları (Yayımlanmamış yüksek lisans tezi). Gaziosmanpaşa Üniversitesi, Sosyal Bilimler Enstitüsü, Tokat.

Koçak, C. (2013). Metaphorical perceptions of teacher candidates towards the school concept: lotus flower model. Mevlana International Journal of Education, 3(4), 4356.

Korkmaz, M. (2005). Okul yöneticilerinin yetiştirilmesi: sorunlar-çözümler, öneriler. Gazi Ĕ̈itim Fakültesi Dergisi, 25(3), 237-252. 
Lakoff, G., \& Johson, M. (2003). Metaphors we live by. Chicago: University of Chicago Press.

Levine, P. M. (2005). Metaphors and images of classrooms. Kappa Delta Pi Record, 41(4), 172-175.

Linn G. B., Sherman R. \& Gill P. B. (2007). Making meaning of educational leadership: the principalship in metaphor. NASSP Bulletin, 91(2), 161-171.

Lum, B. J. (1997). Student Mentality: Intentionalist perspectives about the principal. Journal of Educational Administration, 35, 210-235.

Mahlios, M., \& Maxson, M. (1998). Metaphors as structures for elementary and secondary preservice teachers thinking. International Journal of Educational Research, 29, 227-240.

McMillan, James H. (2004). Educational research: Fundamentals for the consumer, Boston, MA: Pearson Education.

Memduhoğlu, H. B., Mazlum, M. M. (2014). Bir değişim hikayesi: eğitim denetmenlerine ilişkin metaforik algılar. Trakya Üniversitesi Ĕ̈itim Fakültesi Dergisi, 4(1), 28-47.

Miles, M. B., \& Huberman, A. M. (1994). Qualitative data analysis: An expanded sourcebook. London, United States of America: SAGE.

Monroe, C. E. (2003). An analysis of principalship metaphors at the beginning of the new millennium. (Unpublished master thesis). Faculty of the Graduate School, The University of North Carolina, Greensboro.

Morrison, H. (2007). Promising leadership practices, changing role of the middle level and high school leader: Learning from the past preparing for the future. National Association of Secondary School Principals, 19-30.

Nalçacı, A., \& Bektaş, F. (2012). Öğretmen adaylarının okul kavramına ilişkin algıları. Ahi Evran Üniversitesi Kırşehir Ĕ̆itim Fakültesi Dergisi, 13(1), 239-258.

Nikitina, L., \& Furuoka, F. (2008). Measuring metaphors: A factor analysis of students' conceptions of language teachers. Metaphoric. de, 15, 161-180.

Ocak, G., \& Gündüz, M. (2006). Eğitim fakültesini yeni kazanan öğretmen adaylarının öğretmenlik mesleğine giriş dersini almadan önce ve aldıktan sonra öğretmenlik mesleği hakkındaki metaforlarının karşılaştırılması. Afyon Kocatepe Üniversitesi Sosyal Bilimler Dergisi, 8(2), 293-310.

Oğuz, A. (2009). Öğretmen adaylarına göre orta öğretim öğretmenlerini temsil eden metaforlar. Milli Ë̆itim Dergisi, 182, 36-56.

Oxford, R. L., Tomlinson, S., Barcelos, A., Harrington, C., Lavine, R. Z., Saleh, A., \& Longhini, A. (1998). Clashing metaphors about classroom teachers: toward a systematic typology for the language teaching field. System: An International Journal of Educational Tecnology and Applied Linguistics, 26(1), 3-51.

Örücü, D. (2014). Öğretmen adaylarının okul, okul yönetimi ve Türk eğitim sistemine yönelik metaforik algıları. Kuram ve Uygulamada Eğitim Yönetimi, 20(3), 327-358. 
Özdemir, M. (2012). Lise öğrencilerinin metaforik okul algılarının çeşitli değişkenler bakımından incelenmesi. Eğitim ve Bilim, 37(163), 96-109.

Özdemir, T. Y., Erol, Y. C. (2015). Pedagojik formasyon eğitimi alan öğretmen adaylarının okul, öğretmenlik ve öğrenci kavramlarına ilişkin algıları. Celal Bayar Üniversitesi Sosyal Bilimler Dergisi, 13, 215-244.

Palmquist, R. A. (2001). Cognitive style and users' metaphors for the web: An exploratory study. The Journal of Academic Librarianship, 27(1), 24-32.

Pantina, P. A. (1991). Metaphor and the high school principalship. (Unpublished doctorate thesis). Hofstra University, New York.

Pesen, A., Kara, İ., \& Gedik, M. (2015). Çocuk gelişimi bölümü 2. sinıf öğrencilerinin "müdür" kavramına ilişkin metafor algıları. Siirt Üniversitesi Sosyal Bilimler Dergisi, 5, 28-48.

Pipen, T. (2001). Metaphors and organizational identity in the Italian puplic services. Scandinavian Journal of Management, 16, 391-409.

Saban, A. (2004). Giriş düzeyindeki sınıf öğretmeni adaylarının “öğretmen” kavramına ilişkin ileri sürdükleri metaforlar. Türk Eğitim Bilimleri Dergisi, 2(2), 131-155.

Saban, A., Koçbeker, B. N., \& Saban, A. (2006). Öğretmen adaylarının öğretmen kavramına ilişkin algılarının metafor analizi yoluyla incelenmesi. Kuram ve Uygulamada Eğitim Bilimleri, 6(2), 461-522.

Saban, A. (2008). Okula ilişkin metaforlar. Kuram ve Uygulamada Ĕ̈itim Yönetimi, 14(55), 459-496.

Saban, A. (2009). Öğretmen adaylarının öğrenci kavramına ilişkin sahip oldukları zihinsel imgeler. Türk Ĕ̈itim Bilimleri Dergisi, 7(2), 281-326.

Semerci, Ç. (2007). Program geliştirme kavramına ilişkin metaforlarla yeni ilköğretim programlarına farklı bir bakış. Cumhuriyet Üniversitesi Sosyal Bilimler Dergisi, 31(2), 125-140.

Shaw, D. M., \& Mahlios, M. (2008). Pre-service teachers' metaphors of teaching and literacy. Reading Psychology, 29(1), 31-60.

Shuell, T. J. (1990). Teaching and learning as problem solving. Theory into Practice, 29(2), 102-108.

Taşdemir, A., \& Taşdemir, M. (2011). Metaphors on teaching process and teachers; produced by the teachers, 2nd International Conference on New Trends in Education and Their Implications 27-29 April, 2011 Antalya-Turkey, 785-794.

TDK (2017). http://www.tdk.gov.tr/index. php?option=com_gts\&arama=gts\&guid= TDK.GTS.5919ced8ab6550.89412504 (Erişim Tarihi: 15/05/2017).

Trnavcevic, A., \& Vaupot, S. R. (2009). Exploring aspiring principals perceptions of principalship (a Slovenian case study). Educational Management Administration \& Leadership, 37(1), 85-105. 
Toker Gökçe, A., \& Bülbül, T. (2014). Okul bir insan bedenidir: Meslek lisesi öğrencilerinin okul algılarına yönelik bir metafor çalışması. Eğitim Bilimleri Araştırma Dergisi, 4(1), 63-88.

Töremen, F., \& Döş, İ. (2009). İlköğretim öğretmenlerinin müfettişlik kavramına ilişkin metaforik algıları. Kuram ve Uygulamada Ë̆itim Bilimleri, 9(4), 1973-2012.

Tulunay Ateş, Ö. (2016). Öğrencilerin öğretmen ve okul metaforları. Uluslararası Güncel Eğitim Araştırmaları Dergisi (UGEAD), 2(1), 78-93.

Turan, S., Yıldırım, N., \& Aydoğdu, E. (2012). Okul müdürlerinin kendi görevlerine ilişkin bakış açıları. Pegem Eğitim ve Öğretim Dergisi, 2(3), 63-76.

Tüzel, E., Şahin D. (2014). İlköğretim birinci kademe öğrencilerinin okul yöneticilerine ilişkin metaforları. Adıyaman Üniversitesi Sosyal Bilimler Enstitüsü Dergisi, 17, 355-396.

Usdan, M. (2000). Leadership for student learning: reinventing the principalship. Institute for Educational Leadership, 1-24.

Ünal, A., \& Ünal, E. (2010). Öğretmen ve öğrencilerin rehber öğretmeni algılamalarına ilişsin bir durum çalışması. Uluslararası İnsan Bilimleri Dergisi, 7(2), 919-945.

Yalçın, M. (2011). İlköğretim okullarında okul müdürlerine ilişkin metaforik algılar (Yayımlanmamış yüksek lisans tezi). Gaziosmanpaşa Üniversitesi, Sosyal Bilimler Enstitüsü, Tokat.

Yalçın, M., \& Erginer, A. (2012). İlköğretim okullarında okul müdürüne ilişkin metaforik algılar. Öğretmen Ĕ̆itimi ve Ĕ̆itimcileri Dergisi, 1(2), 229-256.

Yalçın, M., \& Erginer, A. (2014). İlköğretim okulu öğrencilerinin okul müdürü algılarına ilişkin yaptıkları çizimler. Eğitim ve Bilim Dergisi, 39(171), 270-285.

Yalçın, S., Yılmaz, M., \& Karakaya, Y. (2017). Ortaöğretim öğrencilerin rehberlik ve psikolojik danışma servislerine bakış açılarının incelenmesi. International Journal of Eurasia Social Sciences, 8(26), 277-289.

Yıldırım, A., \& Şimşek, H. (2013). Sosyal bilimlerde nitel araştırma yöntemleri. Ankara: Seçkin Yayıncılık.

Yıldırım, N., \& Uğur, M. (2011). Öğrencilerin algısından okul müdür imgelerinin karikatürize ifadeleri. Kastamonu Eğitim Dergisi, 19(2), 409-426.

Y1lmaz, F., Göçen, S., \& Y1lmaz, F. (2013). Öğretmen adaylarının öğretmen kavramına ilişkin algıları: bir metaforik çalışma. Mersin Üniversitesi Eğitim Fakültesi Dergisi, 9(1), 151-164.

Zembat, R., Tunçeli, H. İ., \& Akşin, E. (2015). Okul öncesi öğretmen adaylarının okul yöneticisi kavramına ilişkin algılarına yönelik metafor çalışması. Hacettepe University Faculty of Health Sciences Journal, 1, 446-459.

Zhao, H., Coombs, S., \& Zhou, X. (2009). Developing professional knowledge about teachers through metaphor research: facilitating a process of change. Teacher Development, 14(3), 381-395. 
This is an Open Access article distributed under the terms of the Creative CommonsAttributionNonCommercial-ShareAlike 4.0 International (CC BY-NC-SA 4.0). For further information, you can refer to https://creativecommons.org/licenses/by-nc-sa/4.0/ 